\title{
Behandeling van een chronische huidwonde bij een hond via negatieve druktherapie
}

\author{
Treatment of a chronic skin wound in a dog, using negative pressure \\ wound therapy
}

\begin{abstract}
S. Lippens, A. Furcas, M. Or, B. Van Goethem, I. Polis, H. de Rooster
Vakgroep Geneeskunde en Klinische Biologie van de Kleine Huisdieren, Faculteit Diergeneeskunde, Universiteit Gent, Salisburylaan 133, B-9820 Merelbeke, België

hilde.derooster@ugent.be
\end{abstract}

\section{AMENVATTING}

Een vier jaar en acht maanden oude whippet werd aangeboden met een chronische huidwonde ter hoogte van het mediale aspect van de rechterelleboog. Wegens de chroniciteit van de wonde werd het wondbed eerst zorgvuldig gedebrideerd en nadien behandeld met negatieve druktherapie. Deze relatief nieuwe techniek in de diergeneeskunde biedt allerlei voordelen die het genezingsproces van een chronische wonde ten goede komen. In de huidige casus leidde de negatieve druktherapie in eerste instantie tot de snelle ontwikkeling van een mooi granulatiebed. Om een optimaal eindresultaat te bekomen werd daaropvolgend gebruik gemaakt van een autologe huidtransplantatie ("full-thickness mesh graft"), die eveneens onder negatieve druktherapie werd geplaatst. Dit zorgde, ondanks de lastige lokalisatie van de wonde, voor een snelle aanhechting en optimale overleving van de huidgreffe. Na amper vier weken was de wonde nagenoeg volledig geheeld, terwijl ze eerder, ondanks allerlei behandelingen, gedurende meer dan twee maanden geen genezing vertoonde.

\begin{abstract}
A four-year-and-eight-month-old whippet was presented with a chronic skin wound situated at the medial aspect of the right elbow. Because of its chronic nature, the wound was initially carefully debrided and subsequently treated by means of negative pressure therapy. This fairly new technique offers a wide range of advantages that improve the healing capacities of a chronic wound. The beneficial effect of negative pressure wound therapy on the development of a nice granulation bed was clear. In order to optimize the final result, an autologous skin grafting (full-thickness free mesh graft) was performed. By applying negative pressure on the skin graft, a quick and solid attachment of the graft was achieved. After a period of four weeks, the wound was almost completely healed despite various earlier attempts to successfully treat that wound in the two-months period prior to referral.
\end{abstract}

\section{INLEIDING}

Het chronisch worden van een huidwonde bij huisdieren kan verschillende oorzaken hebben. Een aantal belangrijke factoren die een slechte wondheling veroorzaken, zijn bacteriële contaminatie en/of (laaggradige) infectie van het wondbed, de aanwezigheid van necrotisch of neoplastisch weefsel, het achterblijven van vreemde voorwerpen, aanhoudend trauma, een slechte doorbloeding of combinaties ervan (Demidova-Rice et al., 2012). De meeste helingremmende factoren kunnen evenwel dankzij een aangepaste behandeling onder controle gebracht worden.
Negatieve druktherapie is een relatief recente vorm van wondbehandeling in de diergeneeskunde, maar wordt al langer toegepast in de humane wondzorg (Argenta en Morykwas, 1997). De therapie kan aangewend worden bij zowel acute, subacute als chronische wonden (Argenta en Morykwas, 1997; Spillebeen et al., 2013). Negatieve druktherapie bevordert de wondheling door het creëren van een betere doorbloeding en door het stimuleren van de vorming van granulatieweefsel (Jacobs et al., 2009; Demaria et al., 2011). Bij het aanleggen van een negatievedruktherapieverband wordt het wondbed volledig bedekt met een schuimverband met een open celstructuur, 
zodat de negatieve druk zich evenredig over de wonde verdeelt. Nadien wordt alles afgedekt met een luchtdichte polyurethaanfolie en wordthet geheel verbonden met een vacuümpomp. Zo ontstaat een gecontroleerd gesloten systeem. Negatieve druktherapie kan op verschillende manieren aangepast worden aan de noden van de wonde. In de eerste plaats zijn verschillende soorten schuimverbanden beschikbaar (Payne en Ambrosio, 2009; Timmer et al., 2009). Ook kan de ingestelde negatieve druk variëren van $25 \mathrm{mmHg}$ tot $500 \mathrm{mmHg}$ (Morykwas et al., 2001; Borgquist et al., 2010a; Borgquist et al., 2010b; Birke-Sorensen et al., 2011). Ten slotte heeft men ook de mogelijkheid om continue of intermitterende negatieve druk aan te leggen (Borgquist et al., 2010b).

De behandeling van grote wonden ter hoogte van de ledematen van honden en katten vereist dikwijls huidtransplantaten (Fowler, 2006). Esthetisch gezien is de beste keuze een vrije huidgreffe, die zowel de dermis als de epidermis ("full-thickness graft") bevat (Swaim, 1990; Pavletic, 1999). De overleving van vrije huidgreffen is volledig afhankelijk van de ingroei van bloedvaatjes vanuit het wondbed. Het postoperatief verband is hierbij enorm belangrijk (Pavletic, 1999). Succesvol getransplanteerde huid vertoont een nagenoeg normale kleur, textuur, elasticiteit en haargroei (Swaim, 1990; Pavletic 1999).

In deze casus wordt een behandeling van een chronische huidwonde beschreven, waarbij conventionele behandelingen niet het gewenste resultaat opleverden. Negatieve druktherapie werd aanvankelijk toegepast om het wondbed te optimaliseren en daarna om het aanslaan van de huidtransplantatie te bevorderen.

\section{CASUÏSTIEK}

Een vrouwelijke, gecastreerde whippet van vier jaar en acht maanden oud werd aangeboden met een huidwonde ter hoogte van het mediale aspect van de rechterelleboog. De wonde was twee maanden eerder ontstaan, vermoedelijk na het vastzitten in een afsluiting. Het oorspronkelijk huiddefect had een grootte van 10 × $20 \mathrm{~cm}$ en kon, gezien de locatie, niet primair gesloten worden. De eerste behandeling bij de eigen dierenarts bestond uit een dagelijkse sessie van lasertherapie en een honingzalfverband. Daarna werden behandelingen geprobeerd met behulp van pinchgreffen en gelverbanden, allemaal echter zonder succes. Op het moment van aanbieden kreeg de hond reeds tien dagen amoxicilline-clavulaanzuur (Clavaseptin, Vétoquinol, België; $15 \mathrm{mg} / \mathrm{kg}$ BID) en carprofen (Rimadyl, Zoetis, België; 2 mg/kg BID).

Tijdens het algemeen lichamelijk onderzoek vertoonde de hond een kalme, algemene indruk. Er waren geen afwijkingen merkbaar, met uitzondering van de wonde ter hoogte van het mediale aspect van de rechterelleboog. De wonde had een glanzend aspect en was $5 \times 9 \mathrm{~cm}$ groot (Figuur 1).
De wonde werd eerst gedebrideerd. Het glanzend weefsel kwam gemakkelijk los van de onderliggende fascie van de spieren. Er werden stalen van het verwijderde weefsel opgestuurd voor bacteriologisch onderzoek. Na curettage was een goede doorbloeding van het wondbed aanwezig. De wondranden werden getrimd, waardoor een huiddefect van 6 op $10 \mathrm{~cm}$ bekomen werd. In afwachting van het resultaat van de kweek werd op de wonde een hydrogel honingverband (L-Mesitran Hydro, Medeco, Nederland) aangebracht en werd de antimicrobiële behandeling stopgezet. Als pijnstiller werd carprofen, $2 \mathrm{mg} / \mathrm{kg}$ BID voorgeschreven.

De bacteriologische kweek was negatief en de hond werd aangeboden voor verdere behandeling onder algemene anesthesie. Het wondbed zag er na twee dagen met honingverband gezonder en actiever uit dan vóór het debridement. Om zo snel mogelijk een gezond en glad granulatiebed te bekomen, werd besloten een negatievedrukwondverband aan te brengen. De huid rondom het defect werd eerst ruim geschoren. Het wondbed werd gespoeld met een steriele fysiologische oplossing $(\mathrm{NaCl}$ 0,9\%, B. Braun, België). De huid rondom de wonde werd daarna gedroogd en met ether vetvrij gemaakt. In het wondbed werd een zwart schuimverband (GranuFoam, KCI Medical B.V., Nederland) geplaatst, zodat het volledige wondoppervlak (maar niet de intacte omliggende huid) bedekt werd. Nadien werd een polyurethaanfolie (VAC-wondfolie, KCI Medical B.V., Nederland) aangebracht over het volledige wondbed met rondom minstens $5 \mathrm{~cm}$ overlapping van de intacte huid (Figuur 2). Centraal op het schuimverband werd in de folie een opening geknipt met een diameter van $2 \mathrm{~cm}$. Over die opening werd de connectieslang (T.R.A.C. Pad, KCI Medical B.V., Nederland) aangebracht, die vervolgens aangesloten werd aan het vacuümtoestel (V.A.C Therapy, KCI Medical B.V., Nederland) (Figuur 3). Er werd een continue negatieve druk van 75 $\mathrm{mmHg}$ aangelegd. Een beschermend verband werd aangebracht.

De hond werd gehospitaliseerd. De negatieve druktherapie werd goed verdragen door de patiënt en er traden geen luchtlekken op. De vochtdrainage was gemiddeld 15 à $20 \mathrm{ml}$ per uur en het wondvocht was licht hemorragisch tot bruin gekleurd. Pijnstilling werd bekomen door het toedienen van tramadolhydrochloride (Tramadol, Eurogenerics N.V., België; $4 \mathrm{mg} / \mathrm{kg}$ BID).

$\mathrm{Na}$ drie dagen werd de hond gesedeerd om het wondbed te inspecteren. Het vacuümtoestel werd 20 minuten voor het verwijderen van het negatievedrukverband uitgeschakeld. De rechtervoorpoot (met de polyurethaanfolie) werd gereinigd met hibiscrub en er werd een steriel veld gecreëerd met alcoholverneveling. Na het creëren van een steriele omgeving werd de polyurethaanfolie gemakkelijk verwijderd met zo weinig mogelijk beschadiging van de omliggende huid. Daarna werd de folie ter hoogte van de 


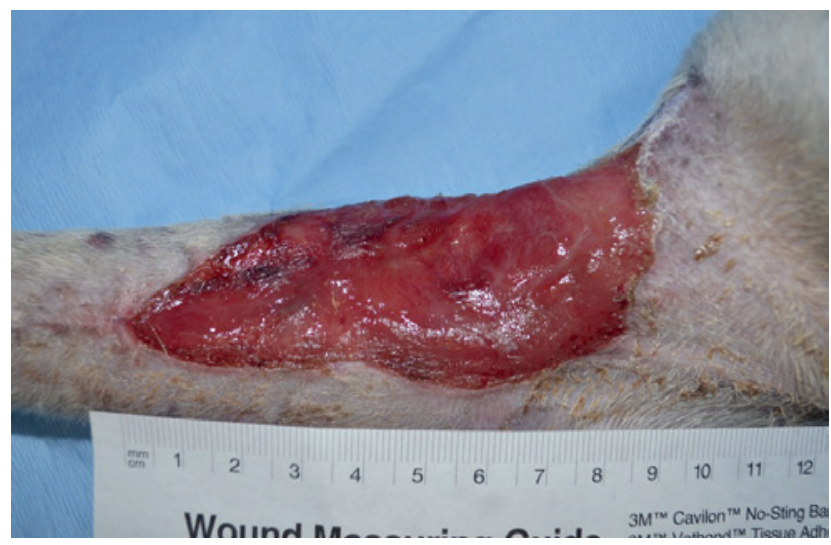

Figuur 1. Macroscopisch beeld van de chronische huidwonde ter hoogte van het mediale aspect van de rechterelleboog van een volwassen whippet. Het wondbed is rood en glanzend.

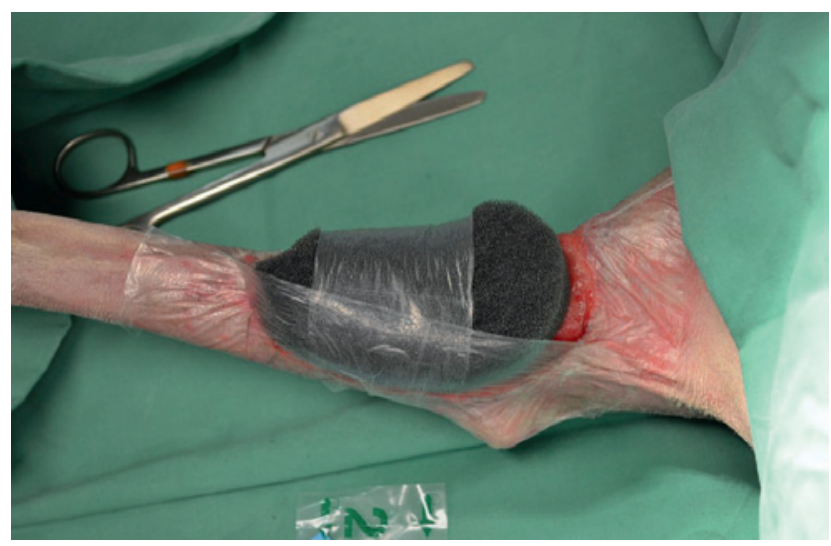

Figuur 2. Foto na het plaatsen van het schuimverband in het wondbed. De omliggende intacte huid werd afgeschermd met behulp van polyurethaanfolie om direct contact met het schuimverband te voorkomen. Een gedeelte van de afsluitende folie werd reeds aangelegd.

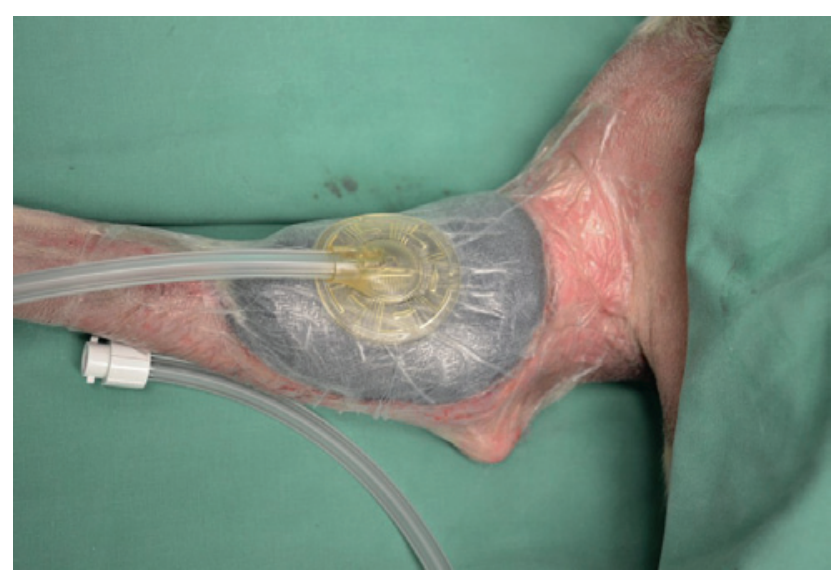

Figuur 3. Afgewerkt negatievedrukverband na het aanbrengen van de connectieslang.

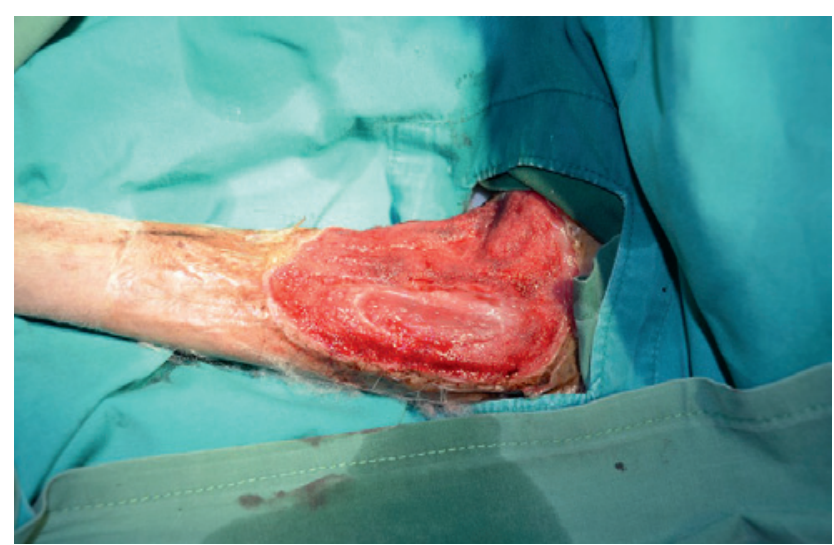

Figuur 4. Wonde na behandeling met negatieve druktherapie gedurende drie dagen. Er is voldoende granulatieweefsel aanwezig in het wondbed om over te gaan tot het plaatsen van een vrije huidgreffe.

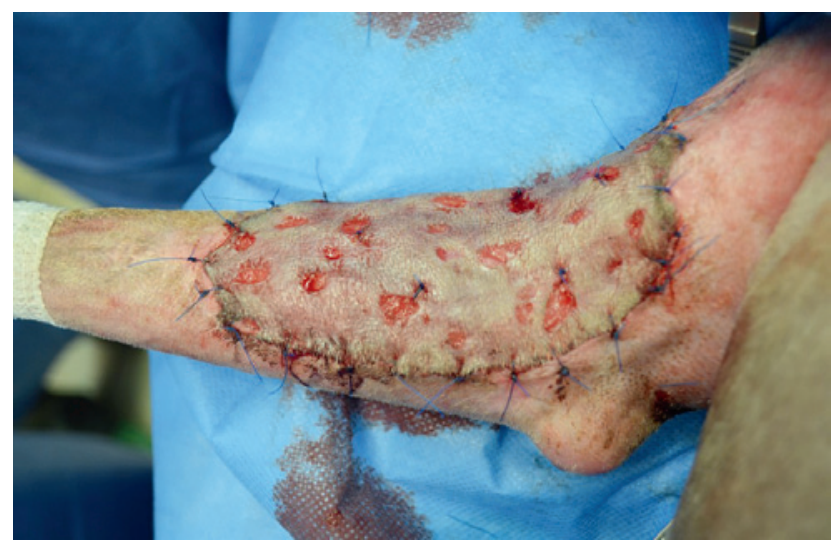

Figuur 5. Voltooiing van de autologe huidtransplantatie. Er zijn niet-resorbeerbare hechtingen aanwezig aan de wondranden alsook ter hoogte van enkele "mesh"incisies.

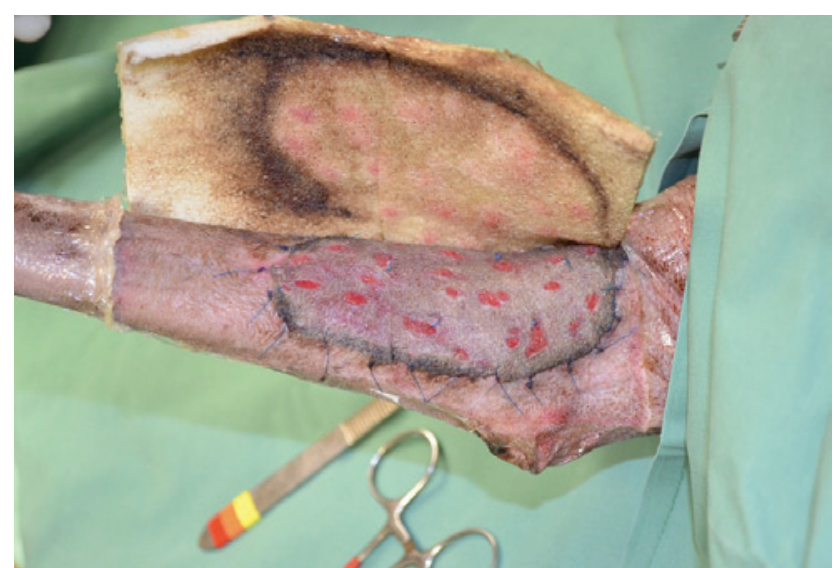

Figuur 6. Het vernieuwen van het negatievedrukverband, drie dagen na de transplantatie. 


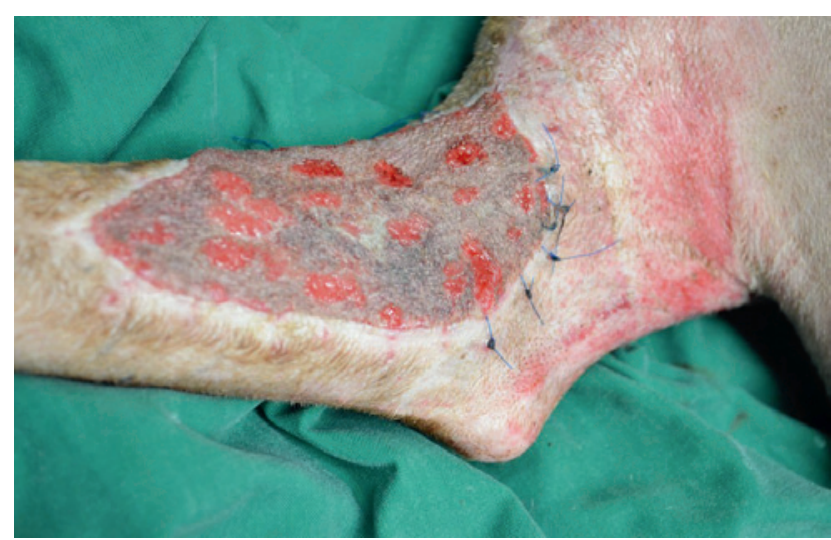

Figuur 7. Resultaat zes dagen na de transplantatie, na het verwijderen van de genecrotiseerde overlappende randen van de huidgreffe en de loszittende huidhechtingen.

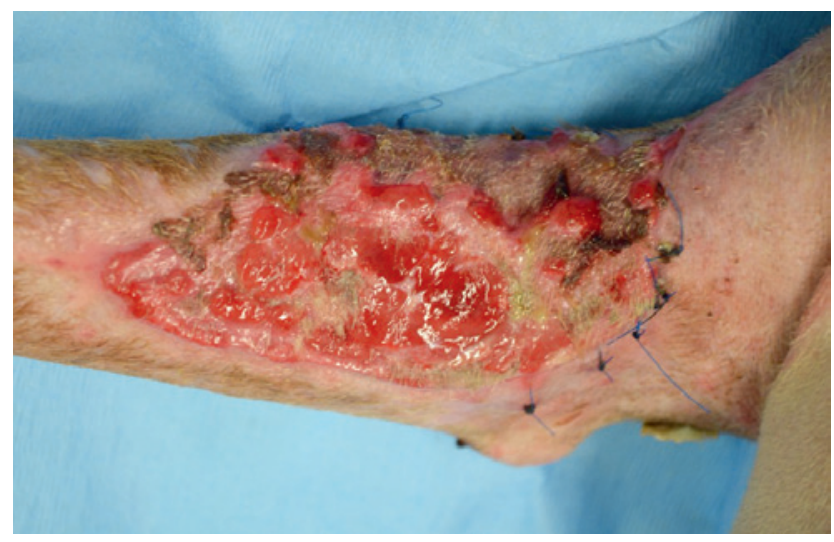

Figuur 8. Uitzicht van de wonde negen dagen na de huidtransplantatie (drie dagen na het verwijderen van het NPWT-verband).

wondranden voorzichtig ingesneden met behulp van een scalpel en een schaar. Het schuimverband liet gemakkelijk los van het wondbed. Er was duidelijk jong vaatbindweefsel aanwezig (Figuur 4). De wonde werd gespoeld met een steriele fysiologische oplossing en de overblijvende randen van de folie werden verwijderd. Aangezien er voldoende activatie van het wondbed was, werd beslist om over te gaan tot de autologe huidtransplantatie. De wonde werd in de tussentijd beschermd met een hydraterende gel op waterbasis (IntraSite gel, Smith \& Nephew, België) met daarboven niet-adhesieve kompressen (Melolin, Smith \& Nephew, België) en een polsterverband.

De volgende dag werd de hond verdoofd en in een rechts laterale positie geplaatst. De exacte plaats waar de huiddonorflap genomen moest worden, werd preoperatief afgetekend met een chirurgische markeerstift. Er werd gebruik gemaakt van donorhuid afkomstig van de linkerflank met een grootte van $6 \times 10$ $\mathrm{cm}$ in longitudinale richting voor een "full-thickness mesh graft". Het donordefect werd nadien routinematig in drie lagen gesloten. De diepe subcutis, de subcutis en de huid werden achtereenvolgens gehecht met polyglecaprone (Monocryl, Ethicon, België). Ondertussen werd de donorhuid voorbereid voor transplan-

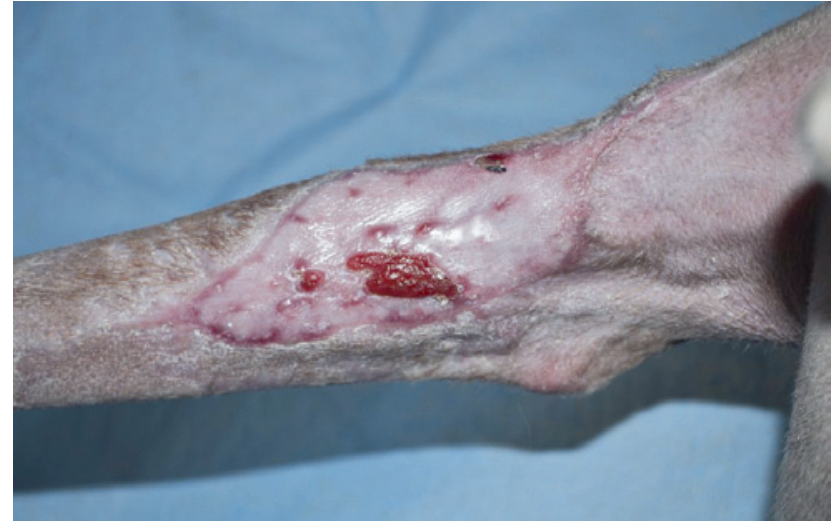

Figuur 9. Uitzicht van de wonde 18 dagen na de huidtransplantatie. Er is epithelialisatie te zien ter hoogte van de "mesh"-openingen.

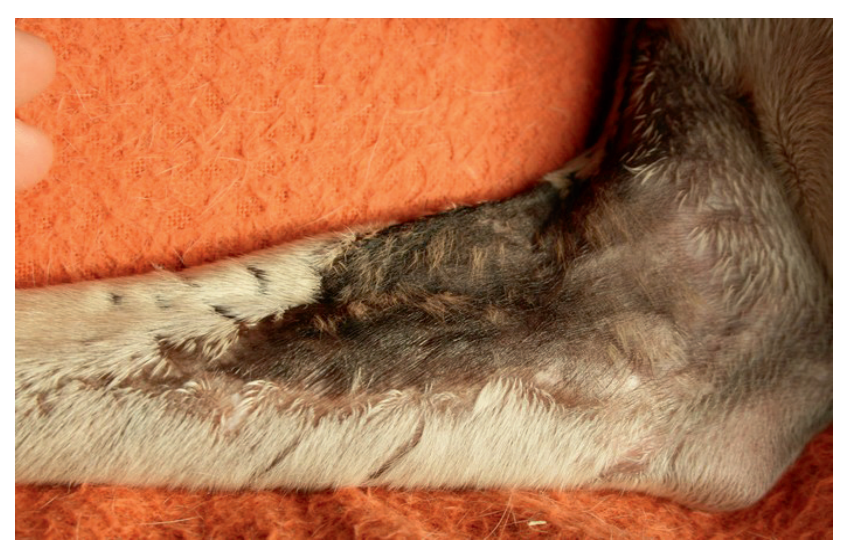

Figuur 10. Uitzicht van de wonde een jaar na de operatie. Er is diffuse beharing zichtbaar.

tatie. Daarbij werden de huidspier en het vet volledig verwijderd tot op het niveau van de haarfollikels. Ten slotte werden multipele longitudinale "mesh"-incisies gemaakt, met een lengte van ongeveer $1 \mathrm{~cm}$. De huidgreffe werd aan de wondranden verankerd met $4 / 0$ polyamide (Ethilon, Ethicon, België) met een overlapping van $0,5 \mathrm{~cm}$. Om de huidgreffe voldoende goed te verankeren met het wondbed werden bijkomend vier hechtingen geplaatst doorheen de mesh-incisies (Figuur 5).

$\mathrm{Na}$ het aanbrengen van de vrije huidgreffe werd opnieuw een negatievedruktherapieverband aangelegd met een negatieve druk van $75 \mathrm{mmHg}$. Over de greffe en de intacte omliggende huid werden ditmaal twee witte polyvinylalcohol-schuimverbanden (WhiteFoam, KCI Medical B.V., Nederland) aangebracht die met polyurethaan wondfolie luchtdicht gefixeerd werden. De beweging ter hoogte van de rechterelleboog werd bijkomend gelimiteerd met een lateraal geplaatst spalkverband.

$\mathrm{Na}$ drie dagen werd de wonde geëvalueerd. De wondvochtproductie was minimaal. De huidgreffe bleek goed aan te slaan en het wondbed was goed droog. Het deel van de huidgreffe dat het oorspronkelijke wondbed bedekte, was roze tot lavendelkleurig; 
ter hoogte van de randen van de huidgreffe die de gezonde huid overlapten, was de greffe grauw van kleur (Figuur 6). In de mesh-openingen was granulatieweefsel zichtbaar. Opnieuw werden witte schuimverbanden en een spalk aangebracht en de negatieve druktherapie werd verdergezet aan $75 \mathrm{mmHg}$ tijdens een tweede cyclus van drie dagen.

$\mathrm{Na}$ de tweede cyclus was de huidgreffe volledig aangeslagen en waren alle mesh-openingen volledig opgevuld met granulatieweefsel (Figuur 7). Enkel de randen van de huidgreffe die de gezonde huid overlapten, vertoonden droge necrose en werden verwijderd, samen met de loszittende hechtingen. De wonde werd afgeschermd door het plaatsen van een droog verband met een niet-adhesief kompres als contactlaag. De patiënt mocht vervolgens met de eigenaren terug naar huis. Qua medicatie kreeg ze nog tramadolhydrochloride $4 \mathrm{mg} / \mathrm{kg}$ BID.

De hond werd drie dagen later opnieuw aangeboden voor een verbandwissel. Het verband zat nog mooi ter plaatse en de transplantatie zat goed vast op het wondbed maar anderzijds waren er verschillende erosies van het oppervlakte-epitheel zichtbaar in het caudomediale deel van het wondbed (Figuur 8). Er werd een nieuw verband geplaatst, doch deze keer werd een dunne laag IntraSite-gel aangebracht op de niet-adhesieve kompressen om een vochtiger milieu te waarborgen.

Dertien dagen na de transplantatie werd het verband er opnieuw afgehaald. De wonde vertoonde een goede epithelialisatie over $70 \%$ van de wondoppervlakte en een milde hypergranulatie over $30 \%$ van de wondoppervlakte. Op de wonde werd een ontsmettende en wondhelende zalf (Neo-Cutigenol, Takeda, België) op niet-adhesieve kompressen (Melolin, Smith \& Nephew, België) aangebracht en het verband werd afgewerkt met een dun laagje cohesief verbandmateriaal (Rinkilastic, Karl Otto Braun, Duitsland). De eigenaren werden geadviseerd om tweemaal daags een dunne laag Neo-Cutigenol aan te brengen en de poot te beschermen door middel van niet-adhesieve kompressen en een dun laagje cohesief verbandmateriaal. De wondheling verliep vlot. Achttien dagen na de transplantatie was er reeds diffuse haargroei aanwezig (Figuur 9). Verband en dus verdere afscherming van de poot waren vanaf 25 dagen na de transplantatie niet meer noodzakelijk.

Een jaar na de operatie werden de eigenaren opnieuw gecontacteerd. Ze waren heel tevreden met het cosmetisch resultaat. Op de plaats van de wonde was er diffuus lichte beharing aanwezig (Figuur 10) en ter hoogte van de donorplaats op de rechterflank was enkel nog een dun litteken op te merken.

\section{DISCUSSIE}

De hond in deze casus werd aangeboden met een chronische, niet-helende wonde ter hoogte van het mediale aspect van de elleboog, die reeds twee maanden aanwezig was.

Een eerste belangrijke factor die de normale wondheling kan verhinderen, is de aanwezigheid van bacteriën. Een persisterende infectie veroorzaakt een erge en langdurige ontstekingsreactie (Demetriou en Stein, 2011). De bacteriën, maar ook de ontstekingscellen, produceren matrix metalloproteïnasen (MMPs). Die proteasen zorgen voor een lagere concentratie aan extracellulaire matrix, receptoren en groeifactoren. De cellen die in het wondbed aanwezig zijn, kunnen daardoor niet prolifereren en/of migreren, waardoor de wondheling vertraagd of geïnhibeerd wordt. Bij gecompliceerde wonden kan daarom beter een bacteriologische cultuur ingezet worden van eventueel aanwezige etter of van een diep weefselstaal (Steed, 2004; Demetriou en Stein, 2011). Bij de beschreven casus konden uit het verwijderde granulatieweefsel geen bacteriën gekweekt worden. Aangezien het om een diep weefselstaal ging, was een valsnegatief laboresultaat en dus een persisterende infectie geen waarschijnlijke oorzaak van de chroniciteit van de wonde. Andere factoren die de wondheling kunnen inhiberen, zijn de aanwezigheid van necrotisch of neoplastisch weefsel en/of vreemde voorwerpen (Demetriou en Stein, 2011). Het niet helen van een wonde kan ook te wijten zijn aan aanhoudend trauma of een geringe doorbloeding van het wondbed, waardoor de vorming van granulatieweefsel en vervolgens de epithelialisatie vertraagd worden. Weinig doorbloeding veroorzaakt een ontoereikend metabolisme en onvoldoende aanvoer van voedingsstoffen. Bovendien moet de patiënt een gebalanceerde voeding met een correct gehalte aan glucose, proteïnen, vitaminen en mineralen toegediend krijgen (Swaim en Angarano, 1990; Demetriou en Stein, 2011; Demidova-Rice et al., 2012). In deze casus was er een duidelijk verhaal van trauma en was een geringe doorbloeding hoogstwaarschijnlijk de hoofdoorzaak van de vertraagde heling. De negatieve druktherapie heeft ervoor gezorgd dat die doorbloeding gestimuleerd werd. De bijkomende huidgreffe was noodzakelijk gezien de grootte van de wonde.

Bij grotere wonden ter hoogte van de ledematen stelt zich vaak het probleem dat eenvoudige sluiting niet mogelijk is. Daarenboven is er meestal ook weinig huid in de onmiddellijke omgeving, waardoor het gebruik van lokale flaptechnieken vaak niet mogelijk is. $\mathrm{Bij}$ grote defecten wordt bijgevolg tot een huidtransplantie overgegaan (Fowler, 2006). Wegens de grootte en de lokalisatie van de wonde werd bij de besproken hond besloten om de wonde te sluiten met behulp van een vrije huidgreffe afkomstig van de flank. Onmiddellijk na het debrideren van het wondbed was het echter niet ideaal om een huidtransplantatie uit te voeren wegens de oneffenheid van het wondoppervlak. Het wondbed werd daarom eerst gedurende drie dagen voorbereid met negatieve druktherapie. Negatieve druk kan aangewend worden bij zowel acute 
als subacute en chronische wonden (Argenta en Morykwas, 1997). Het gebruik van negatieve druk werd reeds meermaals beschreven in de humane geneeskunde (Alvarez et al., 2001; DeFranzo et al., 2001; Hersh et al., 2001; Scherer et al., 2002; Blume et al., 2008), maar kent ook een opkomend succes in de diergeneeskunde (Ben-Amotz et al., 2007; Guille et al., 2007; Owen et al., 2009; Demaria et al., 2011). In de literatuur worden verschillende voordelen beschreven van het gebruik van negatieve druktherapie ten opzichte van een conventionele wondbehandeling met diverse wonddressings. Die voordelen zijn te wijten aan vier basismechanismen, namelijk microdeformatie, macrodeformatie, verwijdering van extracellulair vocht en stabilisatie van het milieu van het wondbed (Orgill et al., 2009). Het mechanisme van microdeformatie was de voornaamste reden om negatieve druktherapie ter voorbereiding van het wondbed toe te passen. De mechanische krachten die ontstaan door de negatieve druk, zorgen voor een deformatie van de cellen in en rond de wonde en werken ook in op de extracellulaire matrix (Orgill et al., 2009). De krachten veroorzaken een mechanische stress op de individuele cellen, wat leidt tot een verhoogde proliferatie. Er ontstaat een verhoging van de mitose van de fibroblasten en als gevolg een stimulatie van de vorming van granulatieweefsel. Granulatieweefsel ontstaat dus sneller bij het gebruik van negatieve druktherapie. Volgens het onderzoek van Demaria et al. (2012) is het granulatieweefsel tevens gladder en groeit het niet voorbij de wondranden. Het gladde en mooie granulatieweefsel is in deze casus het belangrijkste voordeel, aangezien een vrije huidgreffe hierop meer kans heeft om aan te slaan dan wanneer het granulatieweefsel een onregelmatig oppervlak vertoont (Pope, 1990). De overige voordelen van de negatieve druktherapie zijn minder belangrijk voor een goede voorbereiding van het wondbed op de huidtransplantatie, maar hebben ook een positieve invloed op de verdere heling van de huidwonde. Macrodeformatie wijst op de contractie van de wonde. Door het aanbrengen van negatieve druk worden de wondranden door schuimverband naar elkaar toe getrokken en ontstaat er dus wondcontractie (Mouës et al., 2004; Orgill et al., 2009). Volgens Demaria et al. (2011) zou die wondcontractie echter enkel duidelijk aanwezig zijn gedurende de eerste week. Nadien is de wondcontractie zelfs kleiner dan bij conventionele wondbehandeling. Als voorbereiding op een huidtransplantatie is wondcontractie ook voordelig, aangezien er een minder grote huiddonorflap genomen moet worden. Een volgend basismechanisme is het verwijderen van extracellulair vocht. De negatieve druk zorgt voor het verwijderen van interstitieel vocht, waardoor er minder interstitiële druk aanwezig is en de kans op oedeemvorming verlaagt. Bovendien wordt niet alleen interstitieel vocht, maar ook wondexsudaat gelijktijdig verwijderd (Banwell en Musgrave, 2004; Orgill et al., 2009). Ten slotte wordt het milieu ter hoogte van het wondbed stabiel gehouden. Het wondbed is luchtdicht afgesloten door het aanbrengen van een polyurethaan plasticfolie, die tevens ondoorlaatbaar is voor bacteriën en proteïnen (Orgill et al., 2009). De osmotische en oncotische gradiënten blijven stabiel, doordat het aanwezige wondvocht samen met elektrolyten en proteïnen via de afzuigslang verwijderd wordt. Een behandeling met negatieve druk heeft volgens Morykwas et al. (1997) een positieve invloed op het aantal bacteriën in het wondbed. Dit wordt echter weerlegd door een onderzoek van Mouës et al. (2004). Daaruit blijkt dat er geen significant verschil is tussen het aantal aanwezige bacteriën in het wondbed voor en na negatieve druktherapie. Het wondbed in deze casus bleek niet geïnfecteerd te zijn, maar door het aanleggen van een negatievedruktherapieverband werd potentiële contaminatie met nieuwe bacteriën voorkomen. De kans op nieuwe bacteriële contaminatie is echter heel klein, aangezien de suctie continu en altijd weg is van de patiënt.

Voor het aanleggen van de negatieve druk kunnen verschillende soorten schuimverbanden gebruikt worden. Het schuimverband zorgt ervoor dat de subatmosferische druk uniform verdeeld wordt over het wondbed (Argenta en Morykwas, 1997). In deze casus werd voor de eerste applicatie een zwart schuimverband gebruikt. Dat is een polyurethaanschuim met een open celstructuur en een poriegrootte van 400-600 $\mu \mathrm{m}$ (Argenta en Morykwas, 1997). Het polyurethaanschuim is een droog hydrofoob schuimverband, waardoor het wondvocht op een effectieve manier afgevoerd kan worden (Banwell, 2007). Het zwarte polyurethaanschuim wordt het meest gebruikt als schuimverband (Orgill et al., 2009). Een nadeel van het polyurethaanschuim is de grote kans op ingroei van granulatieweefsel tussen de poriën van het schuimverband. Omwille daarvan wordt in de literatuur aangeraden om na twee à drie dagen een verbandwissel uit te voeren (Morykwas et al., 1997; Damaria et al., 2011). In deze casus was er na drie dagen inderdaad ingroei te zien van het granulatieweefsel in het schuimverband, doch dat schuimverband kon verwijderd worden zonder het gevormde granulatieweefsel te beschadigen en zonder partikels van het schuimverband in de wonde achter te laten. Achterblijvende partikels kunnen een vreemd voorwerpreactie of granuloom veroorzaken. Het wondbed is bij achterblijvende partikels ook gevoeliger voor secundaire bacteriële infecties. Door het toepassen van minder hoge negatieve druk, het gebruik van kortere cycli of het gebruik van een schuimverband met kleinere poriën kunnen deze nadelen voorkomen worden. Bij geïnfecteerde wonden kan gebruik gemaakt worden van een polyurethaanschuim dat geïmpregneerd is met metallisch zilver. Naast de aanwezigheid van zilver zijn de eigenschappen gelijk aan die van het gewone polyurethaanschuim. Wanneer het metallisch zilver in contact komt met wondvocht, komen er zilverionen vrij via oxidatie (Payne en Ambrosio, 2009). Die zilverio- 
nen zijn sterk antimicrobieel, aangezien ze in staat zijn om zich te binden aan celwandproteïnen van bacteriën met beschadiging van de bacteriële cel tot gevolg. Bovendien kunnen ze ook binden aan enzymen en bacterieel DNA, waardoor de bacterie niet meer kan functioneren en replicatie onmogelijk wordt (Ovington, 2005). Naast het zwarte polyurethaanschuim kan ook gebruik gemaakt worden van een vochtig wit schuimverband. Het witte schuimverband is een polyvinylalcoholschuim met een kleinere poriegrootte (60-270 $\mu \mathrm{m})$ dan het polyurethaanschuim (400-600 $\mu \mathrm{m})$. Het polyvinylalcoholschuim is hydrofiel. Die eigenschappen maken het witte schuimverband minder gevoelig voor ingroei van granulatieweefsel, waardoor het gebruik ervan aangeraden wordt bij meer delicate weefsels (Timmers et al., 2005). Om beschadiging van de getransplanteerde huid te voorkomen, werd na de huidtransplantatie in de besproken casus gekozen voor een wit schuimverband. Het gebruik van een wit schuimverband is echter weinig beschreven in de diergeneeskundige literatuur (Jordana et al., 2011; Or et al., 2015) maar wordt wel vaker vermeld in de humane geneeskunde (Fleischmann et al., 1995; Fleischmann et al., 1997; Timmers et al., 2005).

Naast de keuze van het type schuimverband kan ook gekozen worden om de negatieve druk continu of intermitterend aan te leggen en aan welke negatieve drukken gewerkt wordt. Bij een intermitterende negatieve druktherapie is er een afwisseling tussen atmosferische en subatmosferische druk. Er kan ook geopteerd worden voor een variabele druk, waarbij er afgewisseld wordt tussen twee verschillende subatmosferische drukken. Wanneer een intermitterende therapie gebruikt wordt, is de doorbloeding van het wondbed beter dan bij een continue therapie (Borgquist et al., 2010b). Ook de vorming van granulatieweefsel is beter bij een intermitterende therapie (Morykwas et al., 1997). Uit humaan onderzoek blijkt echter dat intermitterende druk als oncomfortabel kan ervaren worden door de patiënt (Argenta et al., 2006). Morykwas et al. (2001) raden voor een klassieke wondbehandeling een negatieve druk van $125 \mathrm{mmHg}$ aan, omdat een behandeling met die druk resulteert in een grotere doorbloeding en een verhoogde vorming van granulatieweefsel dan bij behandelingen aan $-25 \mathrm{mmHg}$ of $-500 \mathrm{mmHg}$. Borgquist et al. (2010a, 2010 b) toonden in twee onderzoeken aan dat er geen verschil was in wondcontractie tussen behandelingen met $-75 \mathrm{mmHg}$ en $-125 \mathrm{mmHg}$ en dat de doorbloeding van het wondbed gelijk was bij een behandeling met $-80 \mathrm{mmHg}$ versus $-125 \mathrm{mmHg}$. Bij deze hond werd, omwille van het ras en de dunne huid met weinig subcutis, voorzichtigheidshalve gekozen voor een continue negatieve druk van $75 \mathrm{mmHg}$. Een andere motivatie om een lager negatief drukniveau te selecteren, is wanneer pijn ervaren wordt (Banwell, 2007).

$\mathrm{Na}$ één cyclus met negatieve druk was het wondbed geschikt om de huidtransplantatie uit te voeren. Er werd gebruik gemaakt van een vrije huidgreffe ("full-thickness free mesh graft") die de epidermis en de volledige dermis bevat. De mesh-incisies worden aangebracht om de overleving van de greffe te optimaliseren. De incisies zorgen immers voor een betere aanhechting door een efficiënte afvoer van wondvocht en een betere ingroei van granulatieweefsel (Pope, 1990). Na het plaatsen van een vrije huidgreffe is het aanbrengen van een stevig verband noodzakelijk. Dit zorgt voor absorptie van wondvocht, maar ook voor immobilisatie van de greffe en bescherming tegen uitwendig trauma (Gibbs en Tobias, 2004). In deze casus werd echter niet gekozen voor een conventionele wonddressing, maar opnieuw voor een behandeling met negatieve druk, aangelegd met een wit schuimverband. Daardoor werd het risico op het niet aanslaan van de vrije huidgreffe, door de vorming van een hematoom of seroom onder de greffe, de ontwikkeling van een infectie of beweging van de greffe ten opzichte van het wondbed, sterk verminderd (Ben-Amotz et al., 2007). De combinatie van een huidtransplantatie met een negatievedruktherapieverband wordt in de literatuur meermaals beschreven, humaan (Blackburn et al., 1998; Sposato et al., 2001; Scherer et al., 2002) maar ook diergeneeskundig (Ben-Amotz et al., 2007; Jordana et al., 2011; Stanley et al., 2013). Een eerste voordeel is uiteraard de goede fixatie van de huidgreffe door de aangelegde negatieve druk (Blackburn et al., 2013). In deze casus was dat vermoedelijk het belangrijkste voordeel van de behandeling met negatieve druk. De locatie van de wonde zou immers bij het gebruik van een klassiek verband onderhevig geweest zijn aan schuren. Wanneer een huidgreffe wordt aangebracht met mesh-incisies, zoals ook in deze casus het geval was, zullen de mesh-incisies snel dichtgroeien (Stanley et al., 2013). Ook het verwijderen van vocht met dus minder kans op oedeemvorming, en een goede neovascularisatie zorgen voor een betere kans op het overleven van de huidgreffe (Blackburn et al., 1998; Ben-Amots et al., 2007). Na twee achtereenvolgende cycli met een wit schuimverband en verdere bescherming met een verband was het huiddefect nagenoeg volledig dichtgegroeid.

Indien een "full-thickness mesh graft" goed aanslaat, bestaat de acceptorplaats na genezing hoofdzakelijk uit normale huid met een normale kleur, beharing en textuur, die resistenter is tegen uitwendig trauma (Swaim, 1990). Tijdens het onderzoek van Stanley et al. (2013) werd aangetoond dat er betere haargroei en minder necrose aanwezig waren bij de huidgreffen die behandeld werden met negatieve druk, dan bij huidgreffen die enkel bedekt werden met een conventionele wonddressing. Een jaar na de huidtransplantatie vertoonde de huid bij de beschreven hond echter slechts diffuse beharing en een donkerdere kleur. Hoewel de greffe onder het negatievedruktherapieverband volledig was aangeslagen, traden tijdens de verdere heling huiderosies op die resulteerden in het suboptimale resultaat. Vermoedelijk werden deze veroorzaakt door een schurend effect van 
het conventionele verband dat angelegd werd na het beëindigen van de negatieve druktherapie, mogelijk in combinatie met een te droog wondoppervlak.

Negatieve druktherapie kan de wondheling van huiddefecten positief beïnvloeden door de verschillende fasen van de wondheling te versnellen. Zeker wanneer blijkt dat allerlei conventionele behandelingen niet aanslaan, is het zeker de moeite waard om een behandeling met negatieve druktherapie te overwegen, eventueel in combinatie met een huidgreffe.

\section{LITERATUUR}

Alvarez A.A., Maxwell G.L., Rodriguez G.C. (2001). Vacuum-assisted closure for cutaneous gastrointestinal fistula management. Gynecologic Oncology 80, 413-416.

Argenta L.C., Morykwas M.J. (1997). Vacuum-assisted closure: a new method for wound control and treatment: clinical experience. Annals of Plastic Surgery 38, 563576.

Argenta L.C., Morykwas M.J., Marks M.W., DeFranzo A.J., Molnar J.A., David L.R. (2006). Vacuum-assisted closure: state of clinic art. Plastic and Reconstructive Surgery 117, 127-142.

Banwell P. (2007). V.A.C. ${ }^{\circledR}$ therapy clinical guidelines. A reference source for clinicians. KCI Ltd, 5-9.

Banwell P.E., Musgrave M. (2004). Topical negative pressure therapy: mechanisms and indications. International Wound Journal 1, 95-106.

Ben-Amotz R., Lanz O.I., Miller J.M., Filipowicz D.E., King M.D. (2007). The use of vacuum-assisted closure therapy for the treatment of distal extremity wounds in 15 dogs. Veterinary Surgery 36, 684-690.

Birke-Sorensen H., Malmsjo M., Rome P., Hudson D., Krug E., Berg L., Bruhin A., Caravaggi C., Chariker M., Depoorter M., Dowsett C., Dunn R., Duteille F., Ferreira F., Francos Martinez J.M., Grudzien G., Ichioka S., Ingemansson R., Jeffery S., Lee C., Vig S., Runkel N., Martin R., Smith J. (2011). Evidence-based recommendations for negative pressure wound therapy: treatment variables (pressure levels, wound filler and contact layer) - steps towards an international consensus. Journal of Plastic, Reconstructive \& Aesthetic Surgery 64, 1-16.

Blackburn J.H., Boemi L., Hall W.W., Jeffords K., Hauck R.M., Banducci D.R., Graham W.P. (1998). Negativepressure dressings as a bolster for skin grafts. Annals of Plastic Surgery 40, 453-457.

Blume P.A., Walters J., Payne W., Ayala J., Lantis J. (2008). Comparison of negative pressure wound therapy using vacuum-assisted closure with advanced moist wound therapy in the treatment of diabetic foot ulcers. Diabetes Care 31, 631-636.

Borgquist O., Gustafsson L., Ingemansson R., Malmsjö M. (2010a). Micro- and macromechanical effects on the wound bed of negative pressure wound therapy using gauze and foam. Annals of Plastic Surgery 64, 789-793.

Borgquist O., Ingemansson R., Malmsjö M. (2010b). The effect of intermittent and variable negative pressure wound therapy on wound edge microvascular blood flow. Ostomy Wound Management 56, 60-67.

DeFranzo A.J., Argenta L.C., Marks M.W., Molnar J.A., David L.R., Webb L.X., Ward W.G., Teasdall R.G. (2001). The use of vacuum-assisted closure therapy for the treatment of lower-extremity wounds with exposed bone. Plastic and Reconstructive Surgery 108, 11841191.

Demaria M., Stanley B.J., Hauptman J.G., Steficek B.A., Fritz M.C., Ryan J.M., Lam N.A., Moore T.W., Hadley H.S. (2011). Effects of negative pressure wound therapy on healing of open wounds in dogs. Veterinary Surgery 40, 658-669.

Demetriou J., Stein S. (2011). Causes and management of complications in wound healing. In Practice 33, 392-400.

Demidova-Rice T.N., Hamblin M.R., Herman I.M. (2012). Acute and impaired wound healing: pathophysiology and current methods for drug delivery, part 1: normal and chronic wounds: biology, causes, and approaches to care. Advances in Skin \& Wound Care 25, 304-314.

Fleischmann W., Becker U., Bischoff M., Hoekstra H. (1995) Vacuum sealing: indication, technique, and results. European Journal of Orthopaedic Surgery \& Traumatology 5, 37-40.

Fleischmann W., Lang E., Russ M. (1997). Vacuum-sealing technique for the treatment of infections. Unfallchirurg 100, 301-304.

Fowler D. (2006). Distal limb and paw injuries. Veterinary Clinics of North America: Small Animal Practice 36, 819-845.

Gibbs A., Tobias K.M. (2004). Skin reconstruction techniques: full-thickness mesh grafts. Veterinary Medicine 99, 882-888.

Guille A.E., Tseng L.W., Orsher R.J. (2007). Use of vacuum-assisted closure for management of a large skin wound in a cat. Journal of the American Veterinary Medical Association 230, 1669-1673.

Hersh R.E., Jack J.M., Dahman M.I., Morgan R.F., Drake D.B. (2001). The vacuum-assisted closure device as a bridge to sternal wound closure. Annals of Plastic Surgery 46, 250-254.

Hosgood G. (2006). Stages of wound healing and their clinical relevance. Veterinary Clinics of North America: Small Animal Practice 36, 667-685.

Jacobs S., Simhaee D.A., Marsano A., Fomovsky G.M., Niedt G., Wu J.K. (2009). Efficacy and mechanisms of vacuum-assisted closure (VAC) therapy in promoting wound healing: a rodent model. Journal of Plastic, Reconstructive \& Aesthetic Surgery 62, 1331-1338.

Jordana M., Pint E., Martens A. (2011). The use of vacuümassisted wound closure to enhance skin graft acceptance in a horse. Vlaams Diergeneeskundig Tijdschrift 80, 343350.

Pavletic M.M. (1999). Free grafts. In: Pavletic M.M. (editor). Atlas of Small Animal Reconstructive Surgery. Tweede editie, W.B. Sounders Company, Pennsylvania, p. 275-295.

Morykwas M.J., Argenta L.C., Shelton-Brown E.I., McGuirt W. (1997). Vacuum-assisted closure: a new method for wound control and treatment: animal studies and basic foundation. Annals of Plastic Surgery 38, 553-562.

Morykwas M.J., Faler B.J., Pearce D.J., Argenta L.C. (2001). Effects of varying levels of subatmospheric pressure on the rate of granulation tissue formation in experimental wounds in swine. Annals of Plastic Surgery 47, 547-551.

Mouës C.M., Vos M.C., Van Den Bemd G.C., Stijnen T., Hovius S.E. (2004). Bacterial load in relation to vacuumassisted closure wound therapy: a prospective randomized trial. Wound Repair and Regeneration 12, 11-17. 
Or M., Van Goethem B., Polis I., Spillebeen A., Vandekerckhove P., Saunders J., de Rooster H. (2015). Pedicle digital pad transfer and negative pressure wound therapy for reconstruction of the weightbearing surface after complete digital loss in a dog. Veterinary and Comparative Orthopaedics and Traumatology 1, 140-144.

Orgill D.P., Manders E.K., Sumpio B.E., Lee R.C., Attinger C.E., Gurtner G.C., Ehrlich H.P. (2009). The mechanisms of action of vacuum assisted closure: more to learn. Surgery 146, 40-51.

Ovington L.G. (2004). The truth about silver. Ostomy Wound Manage 50, 1-10.

Owen L.J., Hotston-Moore A., Holt P.E. (2009). Vacuumassisted wound closure following urine-induced skin and thigh muscle necrosis in a cat. Veterinary and Comparative Orthopaedics and Traumatology 22, 417-421.

Payne J.L., Ambrosio A.M. (2009). Evaluation of an antimicrobial silver foam dressing for use with V.A.C.® therapy: morphological, mechanical, and antimicrobial properties. Journal of Biomedical Materials Research Part B: Applied Biomaterials 89B, 217-222.

Pope E.R. (1990). Mesh skin grafting. Veterinary Clinics of North America: Small Animal Practice 20, 177-187.

Scherer L.A., Shiver S., Chang M., Meredith J.W., Owings J.T. (2002). The vacuum assisted closure device. A method of securing skin grafts and improving graft survival. Archives of Surgery 137, 930-934.
Sposato G., Molea G., Di Caprio G., Scioli M., La Rusca I., Ziccardi P. (2001). Ambulant vacuum-assisted closure of skin-graft dressing in the lower limbs using a portable mini-VAC device. British Journal of Plastic Surgery 54, 235-237.

Stanley B.J., Pitt K.A., Weder C.D., Fritz M.C., Hauptman J.G., Steficek B.A. (2013). Effects of negative pressure wound therapy on healing of free full-thickness skin grafts in dogs. Veterinary Surgery 42, 511-522.

Steed D.L. (2004). Debridement. The American Journal of Surgery 187, 71-74.

Swaim S.F. (1986). The full-thickness mesh graft. Veterinary Medicine 81, 524-531.

Swaim S.F. (1990). Skin grafts. Veterinary Clinics of North America: Small Animal Practice 20, 147-176.

Swaim S.F., Angarano D.W. (1990). Chronic problem wounds of dog limbs. Clinics in Dermatology 8, 175-180.

Timmers M.S., Le Cessie S., Banwell P., Jukema G.N. (2005). The effects of varying degrees of pressure delivered by negative-pressure wound therapy on skin perfusion. Annals of Plastic Surgery 55, 665-671.

Zhou M., Yu A., Wu G., Xia C., Hu X., Qi B. (2012). Role of different negative pressure values in the process of infected wounds healing treated by vacuum-assisted closure: an experimental study. International Wound Journal 9, 1-9.
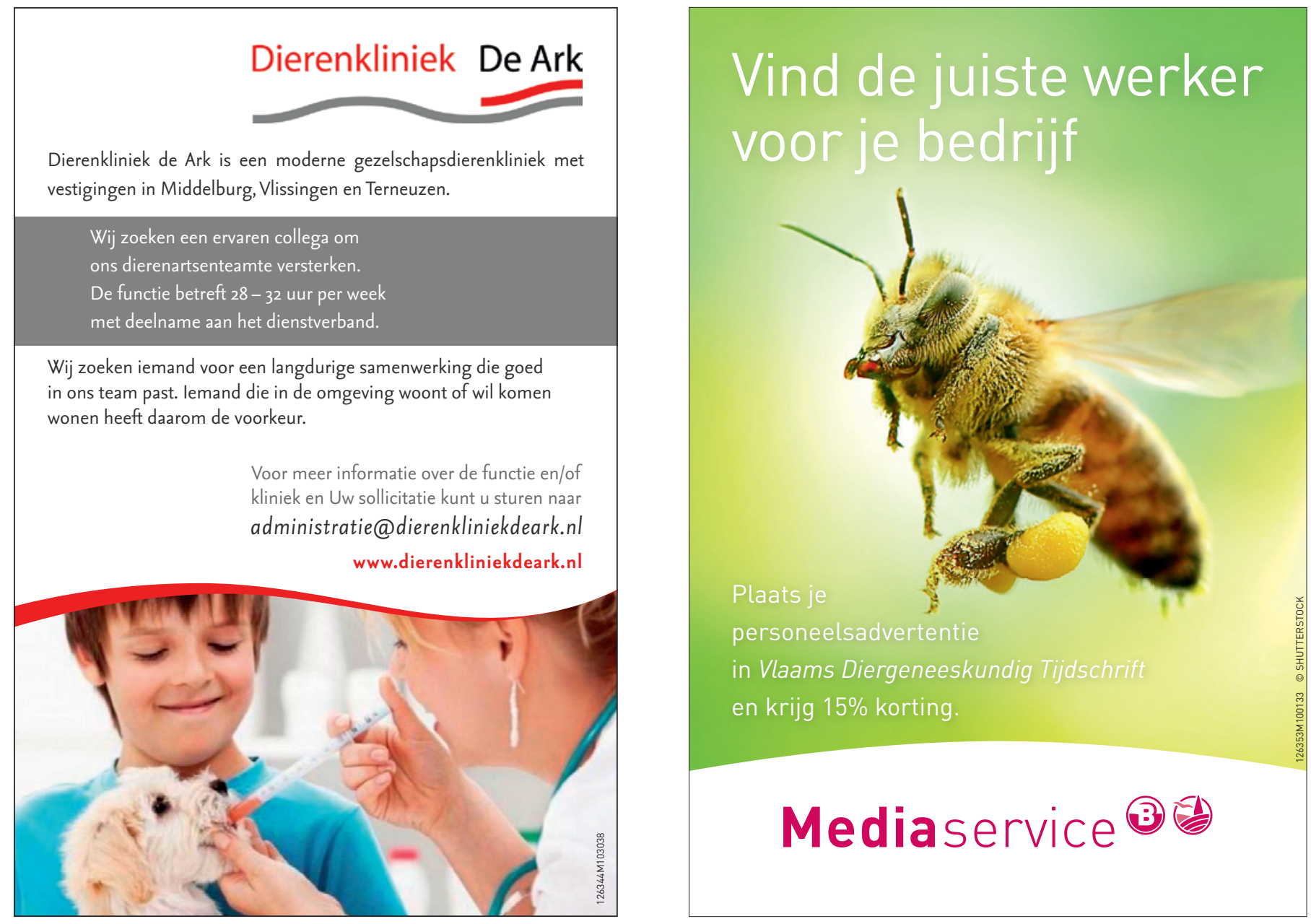